\title{
EDITORIAL
}

Studies in Honour

\section{of Paul Richard}

\section{Blum on the}

\section{Occasion of his}

$70^{\text {th }}$ Birthday

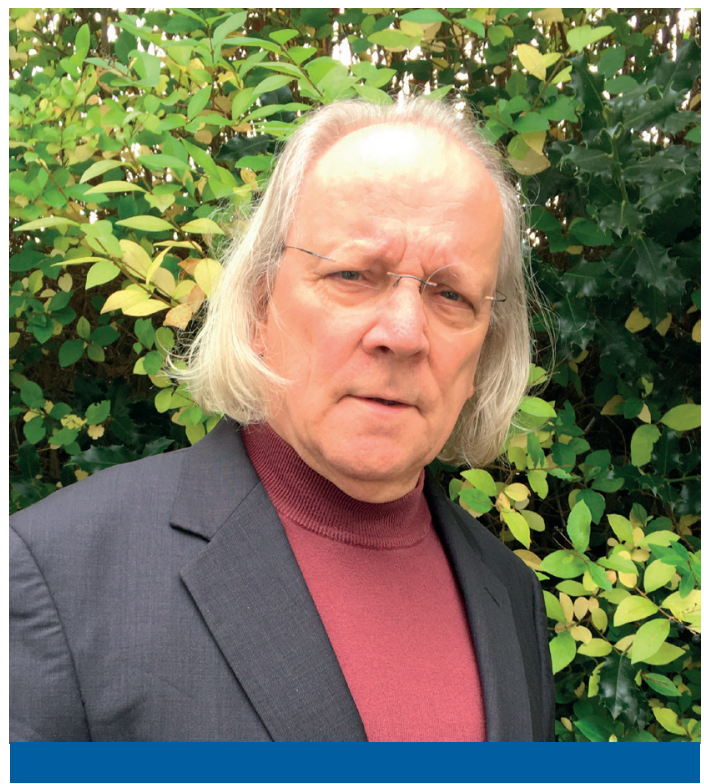

https://doi.org/10.5507/aither.2020.001 
Two international issues of the journal Aither in the year 2020 are of a specific character. Both of these issues only contain articles dealing with Renaissance philosophy, i.e. historically the latest period that the journal Aither is oriented to. The reason is simple. All studies are dedicated to Paul Richard Blum, a renowned Renaissance scholar who celebrated his 70th birthday in May 2020. Both issues as a whole, therefore, are in fact a commemorative publication in honour of P. R. Blum. The articles were written by prof. Blum's friends, colleagues, and former students with the aim to thank him for his friendship and with the hope to continue to enjoy his company and new scholarly contributions in the future.

Volume I (Aither intr. issue 7) consists of seven articles. It is opens with the general study of Thomas Leinkauf "Nachsicht-Fernsicht. Naturerfahrung in der Frühen Neuzeit mit Blick auf die Malerei“ on the issue of perspective from the late Middle Ages to Early modern philosophy. Don Duclow in his study "Charles de Bovelles on God, Nihil and Negative Theology" touches both the mystical theology of Pseudo-Dionysios the Areopagite and the philosophy of Nicolas of Cusa. Jacomien Prins in the article "Heavenly Journeys: Marsilio Ficino and Girolamo Cardano on Scipio's Dream" analyses the differences between these two Renaissance thinkers from the given point of view. Jan Makovský examines Cardano's mathematics and in his study "The Renaissance of Numbers: on Continuity, Nature of Complex numbers and the Symbolic Turn" points out the notion of the 
imaginary quantity in the period before Gauss. The last three studies of the first volume are dedicated to the philosophy of Giordano Bruno. Sergius Kodera's article "The Mastermind of the Fool. Self-Representation and the Shadowy Worlds of Truth in Giordano Bruno's Candelaio (1582)" deals with Bruno's only comedy. Angelika Bönker-Vallon interprets Bruno's understanding of the book Ecclesiastes in the study "Quid est quod est? Der Wahlspruch Giordano Brunos im Licht der Rezeption des alttestamentlichen $\mathrm{Bu}$ ches Ecclesiastes" and Massimiliano Traversino Di Cristo in the article "Anmerkungen zum Christentum von Giordano Bruno auf der Grundlage seines Processes“ analyses Bruno's relationship to some theological concepts and doctrines.

The second volume (Aither intr. issue 8) opens with a study by Jozef Matula on "Erasmus of Rotterdam and his Approach to Tolerance". Then, three articles focusing on Renaissance philosophy mostly from the Venetian area follow. Teodoro Katinis in the study "Sperone Speroni' Della Pace and the Problematic Definition of Concord" not only interprets but also edits and translates Speroni's texts. In the article "The Epistemology of Vernacular Aristotelianism in Renaissance Italy: The Case of Alessandro Piccolomini", Marco Sgarbi examines the contribution of this thinker to the transition from the old scientia to early modern science, and Tomáš Nejeschleba in the study "Francesco Piccolomini's Platonism and Nicolas of Cusa in the "Peripatetic Exercise" of Johannes Jessenius On Divine and Human Philosophy" analyses the context and sources of Jessenius' debate in Padua. In the following article "The Monstrosity of Vice: Sin and Slavery in Campanella's Political Thought" Brian Garcia shows the bound of two conceptions in the works of the famous Italian $17^{\text {th }}$ century philosopher. Then, the issue of evil in Jacob Böhme's thouth is the topic of Martin Žemla's contribution. In the last, but not least, study included in the second volume, "Once Again: Paul Oskar Kristeller and Raymond Klibansky" John Monfasani turns back to the relationship between these two famous Renaissance scholars.

Allow me, as the editor of both volumes, to add some personal notes. I first met Paul Richard Blum in Olomouc. He came to Olomouc to attend the first conferences on the renaissance, which we started to organise at the turn of the $90 \mathrm{~s}$ (on Renaissance Platonism in Central Europe in the year 1998, on Giordano Bruno in the year 2000 and on Nicholas of Cusa in the year 2001). I have, in my memory, the image of a creative man with long hair, active in discussions and friendly in personal interactions, who was ready to help whenever he was asked. Long years of cooperation followed, we met at various conferences and actions and during this time our friendship could develop. I remember with gratitude, the time that I unexpectedly met him in the Prague metro and complained to him that I could not get publishing rights for the Czech translation of Eight Philosophers of the Renaissance by Paul Oskar Kristeller. Thanks to Richard's engagement in this, when he immediately contacted John Monfasani, I received contact information for the inheritor in a few days and it was possible for the book to be published in the Czech Republic. 
Then in 2011, when I asked him whether he would like to join our emerging team at the Centre for Renaissance Texts, which was founded in Olomouc as one branch of the continuation of the older Centre for Patristic, Medieval and Renaissance Texts, Paul Richard Blum, to my great joy, accepted my offer. From the year 2012 Richard and his wife Elisabeth Blum would switch between working in Olomouc and working in Baltimore and they became crucial members of our team in Olomouc. Our students greatly appreciated their courses on Renaissance philosophy, as well as their help in recieving stipends in foreign countries. Thanks to Richards contacts we could develop our cooperation with other experts on the Renaissance in the world and organise international conferences: on Georgios Gemistos Plethon in 2013, on Francesco Patrizi in 2014, eventually P. R. Blum was the editor of conference volumes. Thanks to Richard's activities, the centre in Olomouc became known to other centres for Renaissance research around the world. The result of team cooperation led by Richard Blum was e.g. the editing and translation, first into $\mathrm{Czech}$ and then into English, of De immortalitate animae by Gasparo Contarini.

In 2014 Paul Richard Blum once again became a crucial figure in the project "Between Renaissance and Baroque: Philosophy and Knowledge in the Czech Lands within the Wider European Context", of which I was the principal investigator and for which we received support from the Czech Science Foundation. Thanks to his personality and broad perspective, it was possible to join together, in the Czech Republic, the separate fields of study of Renaissance philosophy, the second scholasticism and academic networks in the 17th century with a focus on J. A. Comenius. And thanks primarily to his publications within the project, the project was judged as excellent.

I am extremely happy that this story is not over and that our cooperation continues. P. R. Blum has received support from the Czech Science Foundation to conduct research into panpsychism and pantheism in the Renaissance for the years 2021-2023, some members of the Centre for Renaissance Texts will be taking part in this research.

For this and for many other things, for his friendship and for his academic cooperation, I would like to thank Paul Richard Blum with this, with my name, with the names of all of the authors that took part in this and with the names of many others who come together in congratulating him.

\section{Ad multos annos, gloriosque an-} nos vivas, Paule Richarde!

To conclude, I would also like to thank the individual authors for their contributions and their patience during the processing of their contributions, all anonymous reviewers and language correctors for their work and also the leadership of Aither, which allowed me to prepare these two volumes in honour of P. R. Blum. Special thanks also to Mrs. Elizabeth Blum.

Tomáš Nejeschleba 